\title{
WALENTYNIAŃSKA INTERPRETACJA BIBLIJNEGO OPISU STWORZENIA CZLOWIEKA (RDZ 1, 26-27) W PRZEKAZIE KLEMENSA ALEKSANDRYJSKIEGO
}

Do poznania poglądów walentynian (i ogólnie gnostyków) w sposób znaczący przyczyniło się odkrycie biblioteki w Nag Hammadi (1945). Po dokonaniu tego odkrycia zauważa się znaczący wzrost zainteresowania gnostycyzmem, co potwierdza chociażby dwutomowa publikacji, która powstała jako pokłosie międzynarodowej konferencji poświęconej gnostycyzmowi, zorganizowanej w roku 1978'. Na gruncie polskim warto wspomnieć liczne studia i przekłady (głównie z języka koptyjskiego) autorstwa wybitnego znawcy pism, teologii i systemów gnostyckich prof. Wincentego Myszora ${ }^{2}$ oraz dr Anny Zmorzanki. Również niniejszy artykuł wpisuje się ten nurt pogłębiania wiedzy na temat gnostycyzmu, a szczególnie antropologii i egzegezy zaproponowanej przez walentyniańskiego myśliciela - Theodota.

Celowo sięgnięto w nim po pisma Klemensa Aleksandryjskiego ponieważ jego myśl teologiczna w znacznym stopniu rodziła się w opozycji do tez gnostyków, a szczególnie bazylidian i walentynian ${ }^{3}$. Alain Le Boulluec ${ }^{4}$ ukazywał

${ }^{*}$ Ks. dr hab. Piotr Szczur, prof. KUL - kierownik Katedry Historii Kościoła w Starożytności i Średniowieczu w Instytucie Historii Kościoła i Patrologii na Wydziale Teologii Katolickiego Uniwersytetu Lubelskiego Jana Pawła II; e-mail: p_szczur@kul.pl.

${ }^{1}$ The Rediscovery of Gnosticism: Proceedings of the International Conference on Gnosticism at Yale, New Haven, Connecticut, March 28-31, 1978, ed. Bentley Layton, vol. 1-2, Leiden 1980.

${ }^{2}$ Wykaz prac i przekładów dotyczących gnostycyzmu przygotował S. Longosz: Ks. prof. Wincenty Myszor (22 V 1941 - 19 II 2017). Polski odkrywca gnozy wczesnochrześcijańskiej, VoxP 37 (2017) t. 68, 833-838. Natomiast całość bibliografii opracowała L. Lach-Bartlik, Wykaz drukowanych prac Ks. prof. dr. hab. Wincentego Myszora, VoxP 32 (2012) t. 57, 21-34.

${ }^{3}$ Por. S.R.C. Lilla, Clement of Alexandria: A Study in Christian Platonism and Gnosticism, London 1971, passim (warto nadmienić, że ta monografia jest podstawowym opracowaniem na temat filozoficznego tła nauczania Klemensa); E.A. Clark, Clement's use of Aristotle: The Aristotelian contribution to Clement of Alexandria's refutation of gnosticism, New York 1977; J.L. Kovacs, Clement of Alexandria and the Vallentinian Gnostics, New York 1978; J.E. Davison, Structural Similarities and Dissimilarities in the Thought of Clement of Alexandria and the Valentinians, „Second Century" 3 (1983) 201-217; E. Procter, Christian Controversy in Alexandria: Clement's Polemic against the Basilideans and Valentinians, New York 1995; M. Edwards, Catholicity and Heresy in the Early Church, Farnham 2009, 57-64.

${ }^{4} \mathrm{~A}$. Le Boulluec, Le notion d'hérésie dans la littérature grecque, II'-III siècles, vol. 2: Clément 
tę prawidłowość widoczną w egzegezie i teologii Klemensa. Współcześnie, w nawiązaniu do nauki Walentyna, Judith Kowacs wydała kilka artykułów na temat antywalentyniańskiej Klemensowej interpretacji Pisma Świętego (szczególnie czerpiąc z jego interpretacji listów św. Pawła $)^{5}$. W niniejszym opracowanie postanowiono skupić się na przekazach Klemensa, zawartych przede wszystkim w Wypisach z Theodota, dotyczących walentyniańskiej interpretacji tekstu biblijnego opisującego stworzenie człowieka (por. Rdz 1, 26-27).

Doskonale wiadomo, że Klemens stale odpiera heterodoksyjną interpretację Pisma Świętego. Mówiąc o różnych interpretacjach Biblii Aleksandryjczyk przyznaje pierwszeństwo jednym interpretatorom nad innymi. Czyni tak $\mathrm{z}$ dwóch powodów. Pierwszym jest zastosowanie reguły wiary. Jednak nad tym elementem Klemens nie rozwodzi się tak, jak moglibyśmy oczekiwać (szczególnie zważywszy na zainteresowania współczesnych mu pisarzy ${ }^{6}$ ) i chociaż w jego pismach nie pojawia się sformułowanie „reguły wiary”, to jednak po-

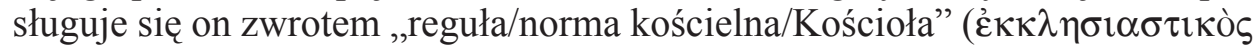
$\kappa \alpha \nu \omega ́ v)^{7}$ jako jego synonimem ${ }^{8}$. Drugim jest przywilej dany prawdziwemu

d'Alexandrie et Origène, Études Augustiniennes, Paris 1985; tenże, Exégèse et polémique antignostique chez Irénée et Clément d'Alexandrie: l'example du centon, StPatr 17 (1982) 707-713.

${ }^{5}$ J.L. Kovacs, Grace and Works: Clement of Alexandria's Response to Valentinian Exegesis of Paul, w: Ancient Perspectives on Paul, ed. T. Nicklas - A. Merkt - J. Verheyden, Göttingen 2013, 191-210; taż, Echoes of Valentinian Exegesis in Clement of Alexandria and Origen, w: Origeniana Octava, ed. L. Perrone, Leuven 2004, 317-329; taż, Clement of Alexandria and Valentinian Exegesis in the „Excerpts from Theodotus”, StPatr 41 (2006) 187-200.

${ }^{6}$ Por. Irenaeus, Adversus haereses I 10, éd. A. Rousseau - L. Doutreleau, SCh 264, Paris 1979, 154-166; III 4, éd. A. Rousseau - L. Doutreleau, SCh 211, Paris 1974, 44-52; Tertullianus, De praescriptione haereticorum 12-25, ed. R.F. Refoulé, CCL 1, Turnhout 1954, 197-207; tenże, Adversus Marcionem III 1 ed. A. Kroymann, CCL 1, 509-510; IV 5, CCL 1, 550-552; tenże, Adversus Praxean 3, ed. A. Kroymann - E. Evans, CCL 2, Turnhout 1954, 1161-1162.

7 „Normę Kościoła” Klemens definiuje w następujący sposób: „Normą Kościoła jest zbieżność i zgodność Prawa i proroków z Nowym Przymierzem zawartym w czasie obecności Pana” (Clemens Alexandrinus, Stromata VI 125, 3, éd. P. Descourtieux, SCh 446, Paris 1999, 310, thum. J. Niemirska-Pliszczyńska, Kobierce zapisków filozoficznych dotyczacych prawdziwej wiedzy, t. 2, Warszawa 1994, 187-188).

${ }^{8}$ Por. Clemens Alexandrinus, Stromata VI 115, 1 - 132, 4, SCh 446, 288-324; VII 93, 1 - 105, 6, éd. A. le Boulluec, SCh 428, Paris 1997, 282-316. Teksty te najwyraźniej pokazują akceptowanie przez Klemensa regula fidei zgodnie z tradycją apostolską. Dowiadujemy się z nich, że reguła wiary jest szczególnie ważna w interpretacji Pisma Świętego, zwłaszcza przy zwalczaniu heretyckich inter-

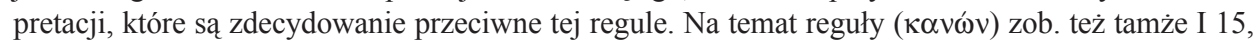

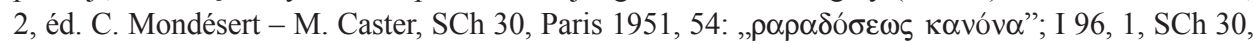

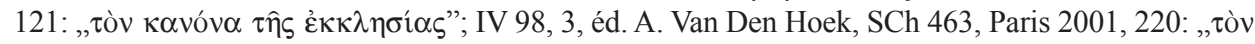

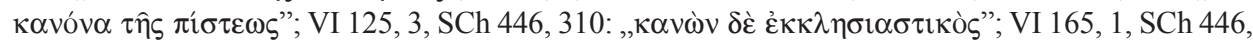

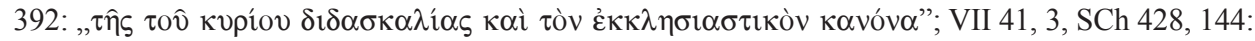

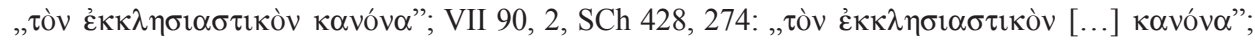

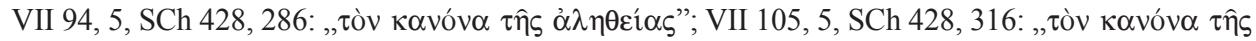

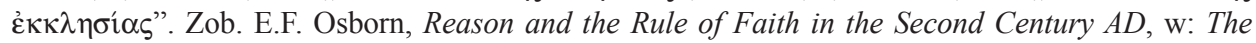


gnostykowi ${ }^{9}$ jako właściwemu interpretatorowi Pisma Świętego. Według Klemensa interpretacja prawdziwego gnostyka posiada pierwszeństwo przed wszystkimi innymi interpretacjami (zwłaszcza heretyckimi), ponieważ jedynie gnostyk może dostrzec Prawdę poprzez zasłonę nałożoną przez Boga na tekst Biblii.

1. Walentyn i jego szkoła. Wydaje się zasadnym, aby na wstępie pokrótce przyjrzeć się postaci herezjarchy Walentyna i jego aktywności nauczycielskiej. Urodził się on ok. roku $100{ }^{10} \mathrm{~W}$ Dolnym Egipcie ${ }^{11}$. Prawdopodobnie pochodził z rodziny chrześcijańskiej. W Aleksandrii otrzymał staranne wykształcenie w duchu tradycji greckiej. Jego nauczycielem mógł być Teodas - uczeń św. Pawła $^{12}$. W Aleksandrii założył pierwszą szkołę i już wtedy zaczął odchodzić od ortodoksji. Ok. roku 136, celem głoszenia swej nauki, wyjechał do Rzymu, gdzie przebywał ok. 30 lat (136-165) ${ }^{13}$. W stolicy Imperium Romanum zyskał znaczną popularność wśród tamtejszych chrześcijan. Prawdopodobnie starał się o godność biskupa Rzymu po śmierci Hygina († ok. 142) ${ }^{14}$, jednak w wyborach poniósł porażkę, m.in. ze względu na nieortodoksyjne poglądy, i zwycięstwo odniósł Pius († ok. 155). Później (ok. 165) prawdopodobnie udał się

Making of Orthodoxy: Essays in Honour of Henry Chadwick, ed. R. Williams, Cambridge 1989, 4046; F.R.M. Hitchcock, The Creed of Clement of Alexandria, „Hermathena” 12 (1902) no 28, 25-28.

${ }^{9}$ Klemens włącza tytułu ,gnostyk” w ideę duchowego postępu, w którym gnoza jest najwyższym możliwym osiągnięciem w doczesnym życiu. Na temat gnozy jako ideału chrześcijańskiego oraz gnostyka jako doskonałego chrześcijanina istnieje wiele prac autorstwa F. Drączkowskiego, przykładowo zob.: Formy i cele modlitwy doskonałego chrześsijanina (gnostyka) wedlug Klemensa Aleksandryjskiego, w: Medytacja, Homo Meditans 1, red. W. Słomka, Lublin 1984, 127-132; Gnoza w ujęciu Klemensa Aleksandryjskiego, SACh 12 (1996) 9-21; Miłość - Agape syntezq chrześcijaństwa, Pelplin - Torun 1997.

${ }^{10}$ Por. P. Siejkowski, Wstęp, w: Klemens Aleksandryjski, Wypisy z Theodota, ŹMT 22, Kraków 2001, 10. W literaturze na ogół podaje się informację, że Walentyn urodził się na początku II w. lub że żył w II w. Szerzej na temat Walentyna zob. A. Zmorzanka, Walentyn, PEF IX 688-690; taż, Walentyn, EK XX 163-164.

${ }^{11}$ Por. G. Quispel, Gnoza, thum. B. Kita, Warszawa 1988, 128.

${ }^{12}$ Por. Clemens Alexandrinus, Stromata VII 106, 4, SCh 428, 318-320, thum. Niemirska-Pliszczyńska, t. 2, s. 306: „Podobnie, jak [gnostycy] utrzymują także, Walentyn był uczniem Theodasa, a przecież ten został uczniem Pawła".

${ }^{13}$ Por. Zmorzanka, Walentyn, EK X 163. Ireneusz z Lyonu (Adversus haereses III 4, 3, SCh 211, 50) informuję, że Walentyn przybył do Rzymu w czasach biskupa Hygina i przebywał w Wiecznym Miście w czasach biskupa Piusa i Aniceta. Informację tę powtarza Euzebiusz z Cezarei (HE IV 11, 1, ed. i tłum. ŹMT 70 [wyd. grecko-polskie, oprac. H. Pietras, tłum. A. Caba na podstawie thum. A. Lisieckiego], Kraków 2013, 239: „Walentyn przybył do Rzymu za czasów Hygina, rozwinął w pełni działalność za Piusa i dożył czasów Aniceta”). Pobyt Walentyna w Rzymie jest różnie datowany. P. Siejkowski (Wstęp, s. 10) wskazuje na lata 136-160; z kolei Quispel (Gnoza, s. 129) przypuszcza, że do Rzymu przybył ok. roku 140.

${ }^{14}$ Por. Tertullianus, Adversus Valentinianos 4, 1, éd. J.-C. Fredouille, SCh 280, Paris 1980, 86. A. Zmorzanka (Walentyn, EK XX 163) informuje, że Walentyn starał się o godność biskupa Rzymu po śmierci Aniceta. Jednak Anicet zmarł ok. roku 166, gdy Walentyn prawdopodobnie już opuścił Rzym. 
na Cypr, gdzie nauczał. Data śmierci Walentyna nie jest znana, jednak Tertulian przekazuje informację, że żył jeszcze za biskupa Eleutera (pontyfikat: ok. 174-189). Pozostawił po sobie wiele dzieł napisanych kunsztownym językiem (m.in. listy, homilie, psalm Żniwo oraz traktat $O$ trzech naturach), z których zachowały się tylko fragmenty ${ }^{15}$.

Uczniowie Walentyna kontynuowali i rozwijali jego naukę ${ }^{16}$. Działali od II do III w. Klemens Aleksandryjski, Hipolit ${ }^{17}$ i Tertulian ${ }^{18}$ przekazują informację, że działali w dwóch szkołach - wschodniej, nazywanej anatolijską ( $\alpha \dot{v} \alpha \tau \Delta \imath \iota \kappa \eta$ $\tau \imath \varsigma \delta \imath \delta \alpha \sigma \kappa \alpha \lambda i \alpha)$ oraz zachodniej, nazywanej italską (i $\tau \alpha \lambda \imath \omega \tau \imath \kappa \eta ́))^{19}$. Do bardziej znanych przedstawicieli szkoły anatolijskiej należeli: Theodot, Marek i Bardesanes. Natomiast bardziej znanymi przedstawicielami szkoły italskiej byli: Floryn, Herakleon, Ptolemeusz i Sekundus. Głosili umiarkowany dualizm oparty przede wszystkim na platonizmie i pitagoreizmie, rozwinęli kosmogonię, naukę o trzech typach (naturach) ludzkich oraz chrystologię; większość walentynian przyjmowała doketyzm, jednak - w zależności od szkoły - odmiennie wyjaśniano kwestię pneumatycznego ciała Chrystusa. Warto też dodać, że herezja walentynian była jednym z najbardziej rozpowszechnionych we wczesnym chrześcijaństwie nurtów heterodoksyjnych ${ }^{20}$.

2. Excerpta ex Theodoto. Traktat ten trudno uważać za dzieło Klemensa Aleksandryjskiego ${ }^{21}$. Faktycznie w Clavis Patrum Graecorum figuruje ono pod imieniem Theodota ${ }^{22}$ - jak już wspomniano - bliżej nieznanego przedstawiciela wschodniej szkoły walentyniańskiej ${ }^{23}$. Wprawdzie Mark Ed-

${ }^{15}$ Istniejące i zidentyfikowane fragmenty zostały wydane w: W. Völker, Quellen zur Geschichte der christlichen Gnosis, Tübingen 1932, 57-60.

${ }^{16}$ Szerzej zob. The Rediscovery of Gnosticism, vol. 1: The School of Vatentinus.

${ }^{17}$ Por. Hippolytus, Refutatio omnuium haeresium VI 35, 5-7, ed. P. Wendland, GCS 26, Leipzig 1916, 165.

${ }^{18}$ Por. Tertullianus, Adversus Valentinianos 11, 2, SCh 280, 104-106.

${ }^{19}$ Einar Thomassen (The Spiritual Seed: The Church of the „Valentinians”, Leiden 2008, 3945) mówi, że istnieje wprawdzie rozróżnienie między szkołami uczniów Walentyna, jednak trudno jest dopatrzeć się tych różnic, gdyż różne źródła różnie przedstawiają te szkoły. Wnioskuje jednak, że różnica pomiędzy „wschodnią” i ,zachodnią” szkołą Walentyna dotyczy głównie soteriologii (tamże, s. 81-82). Jest to zgodne z klasycznym rozumieniem szkół Walentyna obecnym w literaturze, por. np. J.-D. Kaestli, Valentinisme italien et valentinisme oriental: leurs divergences à propos de la nature du corps de Jésus, w: The Rediscovery of Gnosticism, vol. 1, s. 391-403. Niektórzy jednak twierdzą że podział na szkołę „wschodnią” i „zachodnią” jest sztuczny, por. J. Kalvesmaki, Eastern vs. Italian Valentinianism?, VigCh 61 (2008) 79-89.

${ }^{20}$ Por. Tertullianus, Adversus Valentinianos, SCh 280.

${ }^{21}$ Por. A.-J. Festugière, Notes sur les Extraits de Théodote de Clément d'Alexandrie, VigCh 3 (1949) 193-207.

${ }^{22}$ CPG 1139.

${ }^{23} \mathrm{Na}$ temat Theodota zob. W. Myszor, Theodotos, Gnostiker, LThK IX 1425-1426; M. Simonetti, Teodoto valentiniano, NDPAC III 5272. 
wards $^{24}$ sugeruje, że Theodot z Excerpta może być tożsamy z Theodotem z Bizancjum $^{25}$, którego tezy obala Hipolit ${ }^{26}$. François Sagnard wątpi, że to ten sam Theodot, o którym mówią Excerpta, ponieważ Theodot Hipolita jest adopcjanistą, a to jest sprzeczne z doktryną walentynian zawartą w Excerpta; nie sądzi także, że jest to inny Theodot wspomniany przez Hipolita w następnym rozdziale Refutatio $^{27}$ jako uczeń Theodota z Bizancjum ${ }^{28}$.

Najprawdopodobniej tekst Excerpta miał służyć Aleksandryjczykowi (lub komuś innemu) jako podręczne źródło informacji na temat nauki Theodota (czy szerzej: walentynian), a szczególnie jego gnostyckiej interpretacji różnych fragmentów Pisma Świętego. Prawdopodobnie nie był też przeznaczony do późniejszego „opublikowania”. Excerpta są dołączone do rękopisu pism Klemensa i umieszczone między Stromata a Eclogae Propheticae ${ }^{29}$. Wydaje się, że zostały tam umieszczone przez jakiegoś „wydawcę”, który - być może - uważał się za powiernika literackiej spuścizny Klemensa. Publikując pisma aleksandryjskiego scholarchy ,wydawca” udostępnił zbiór powiększony o Excerpta ${ }^{30}$.

Warto jeszcze dodać, że w manuskrypcie, który stanowił podstawę wyda-

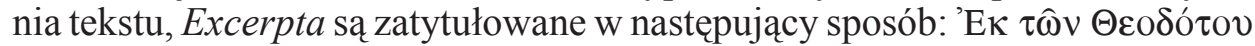

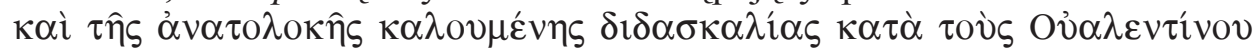

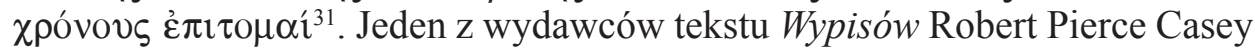
przetłumaczył ten tytuł jako Extracts from the works of Theodotus and the so-called 'oriental teaching' at the time of Valentinus, króry można przełożyć jako Wypisy $z$ dziet Theodota $i$ tak zwane 'wschodnie nauczanie' $w$ czasach Walentyna. Taki przekład tytułu najprawdopodobniej wynikał z jego przekonania, że nie ma żadnej konkretnej szkoły, z którą powinno być kojarzone „wschodnie nauczanie”. Jednak wydaje się, że koncepcje teologiczne obecne w Excerpta, w dużej mierze są równoległe do tzw. wschodniej (czy anatolijskiej) szkoły.

${ }^{24}$ Por. M. Edwards, Clement of Alexandria and his Doctrine of the Logos, VigCh 54 (2000) 175-176.

${ }^{25} \mathrm{Na}$ temat Theodota z Bizancjum zob. W.A. Bienert, Theodotos (der Gerber), LThK IX 1424; M. Simonetti, Teodoto di Bisanzio (Cuoiaio), NDPAC III 5271.

${ }^{26}$ Por. Hippolytus, Refutatio omnuium haeresium VII 35.

${ }^{27}$ Por. tamże VII 36.

${ }^{28}$ Por. F. Sagnard, Introduction, w: Clément d'Alexandrie: Extraits de Théodote, SCh 23, Paris 1948, 5. Na temat Theodota zob. M. Simonetti, Teodoto di Bisanzio (Banchiere), NDPAC III 5271.

${ }^{29}$ Por. Sagnard, Introduction, s. 5. Robert P. Casey (Introduction, w: The Excerpta ex Theodoto of Clement of Alexandria, Edided wirh translation, introduction and notes by R.P. Casey, London 1934, 3-5) i François Sagnard (Introduction, s. 49) zauważają także, że Wypisy zostały przekazane w dwóch manuskryptach: jeden z Florencji - Codex Laurentianus V 3, z XI w., a drugi z Paryżu, Biblioteca Nationale, Supplementa Grecae 250, z XVI w., który jest kopią pierwszego. Por. Siejkowski, Wstęp, s. 13.

${ }^{30}$ Por. Casey, Introduction, s. 3-4.

${ }^{31}$ Clemens Alexandrinus, Excerpta ex Theodoto I 1, éd. F. Sagnard, SCh 23, 52. 
3. Walentyniańska interpretacja $\mathrm{Rdz}$ 1, 26-27 w Excerpta ex Theodoto. Biblijny opis stworzenia człowieka ( $R d z 1,26-27)$ będzie znajdował się w centrum przedstawionych poniżej rozważań, dlatego - ze względu na znaczenie tego passusu biblijnego - zostanie przytoczony w całości, zarówno w wersji Septuaginty, jak i w przekładzie polskim:

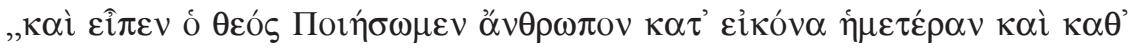

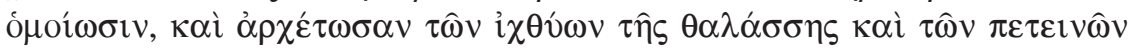

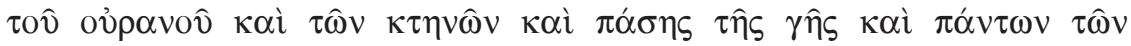

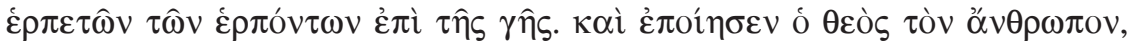

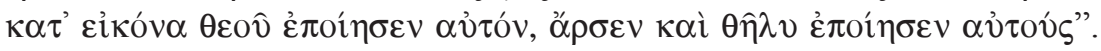

„A wreszcie rzekł Bóg: «Uczyńmy człowieka na Nasz obraz, podobnego Nam. Niech panuje nad rybami morskimi, nad ptactwem powietrznym, nad bydłem, nad całą ziemią i nad wszelkim zwierzątkiem naziemnym!» Stworzył więc Bóg człowieka na swój obraz, na obraz Boży go stworzył: stworzył mężczyznę i niewiastę" (Rdz 1, 26-27).

Interpretacja biblijnego opisu stworzenia człowieka, zaproponowana przez Theodota, zostanie przedstawiona w kontekście nauczania walentynian na temat stworzenia Adama i jego potomstwa.

$\mathrm{Na}$ wstępie należy zauważyć, że walentyniańska interpretacja opisu stworzenia świata (w tym człowieka) stała się - w minionym stuleciu - dobrze znana badaczom wczesnego chrześcijaństwa dzięki odkryciom w Nag Hammadi. Zarówno Ireneusz z Lyonu w Adversus haereses, jak i Hipolit w Refutatio omnium haeresium mówią o tym, co postrzegają jako różne odmiany doktryny walentynian. Z przekazów zawartych w wymienionych pracach polemicznych wynika, że istniały różne szkoły walentynian, a każda z nich starała się wzbogacić nauczanie własnymi elementami dodanymi do mitologii kosmologicznej ${ }^{32}$. Jednak ani Ireneusz, ani Hipolit nie wnoszą wiele do poznania antropologii walentynian.

Hipolit w opisie doktryny walentynian nie poświęca zagadnieniu stworzenia człowieka wiele miejsca, jednak wspomina o trzech różnych elementach, jakie posiadały dusze po stworzeniu rodzaju ludzkiego: 1 . sam dusza; 2 . dusza i demony; 3. dusza i logoi33. Znacznie więcej można dowiedzieć się o antropologii walentynian z notatek Klemensa zawartych w Excerpta ex Theodoto. Wydają się one zgadzać z opisem stworzenia rodzaju ludzkiego przekazywanym przez Hipolita:

„Lecz uczniowie Walentyna głoszą: skoro «ciało psychiczne» zostało ukształtowane, nasienie męskie zostało złożone przez Logos w wybranej duszy, gdy

${ }^{32} \mathrm{Na}$ temat wiarygodności wczesnochrześcijańskich opisów doktryny walentynian i innych sekt zob. M. Desjardins, The Sources for Valentinian Gnosticism: A Question of Methodology, VigCh 40 (1986) 342-347, spec. 345.

${ }^{33}$ Por. Hippolytus, Refutatio omnium haeresium VI 29. 
ta była w śnie. Nasienie to jest wypływem elementu anielskiego, tak aby nie było żadnego braku" 34 .

„Męskie nasienie” może być tu z dużym prawdopodobieństwem postrzegane jako tożsame z logoi z opisu Hipolita. Dalej Klemens kontynuuje swe rozważania mówiąc o walentynianach (ponieważ najwyraźniej nie cytuje tu walentyniańskiego pisarza, ale daje własny komentarz):

„ «Stworzył ich na obraz Boga, stworzył ich mężczyzną i kobietą» (Rdz 1, 27), a jak mówią walentynianie, <ludzie > są najlepszą emanacją Mądrości. To, co męskie, a pochodzące $<$ z tego źródła $>$ jest wybrane; zaś to, co żeńskie stanowi zbiór tego, co powołane. Nazywają oni to, co męskie «pierwiastkiem anielskim», zaś żeńskie - «wyższym nasieniem». Podobnie również w wypadku Adama, element męski pozostał w nim, podczas gdy wszelkie nasienie żeńskie, wypłynęło z niego, tworząc Ewę (por. Rdz 2, 22), z której pochodzą istoty żeńskie, tak jak z Adama istoty męskie. W ten sposób pierwiastki męskie pozostają w ścisłym związku z Logosem. Pierwiastki żeńskie, przemienione w to, co męskie jednoczą się z aniołami i wchodzą w Pleromę"35.

Z przytoczonej wyżej wypowiedzi wynika, że istnieją takie istoty, których przeznaczeniem jest zbawienie oraz takie, które nie będą miały udziału w zbawieniu. Nieco dalej Klemens dokładniej wyjaśnia, że

„Według walentynian, pośród istot powstałych z Adama, jedne, czyli Sprawiedliwi, zwracając się do bytów stworzonych, pozostają zatrzymani w Miejscu. Inne zaś, pozostają w sferze stworzonej dla ciemności, w miejscu «po lewicy», lub też doświadczają ognia"36.

Przedstawione powyżej poglądy walentynian wskazuja, że zbudowany przez nich system jest deterministyczny i nie pozostawia miejsca na wolną wolę jednostki. Ta teoria jest jednym z głównych powodów krytyki Klemensa kierowanej pod adresem sekty. Według walentyniańskiego mitu kosmologicznego, demiurg zasiał różne ,natury” w ludziach, których stworzył.

W swym nauczaniu Klemens kładzie nacisk na prawdę wyrażoną w Księ-

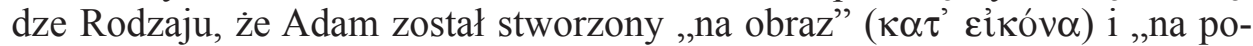

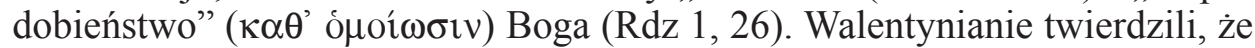
określenia te nie są synonimiczne i odnoszą się raczej do dwóch typów ludzi:

„Demiurg uczynił duszę z ziemi, duszę hyliczną, bezrozumną, współ-

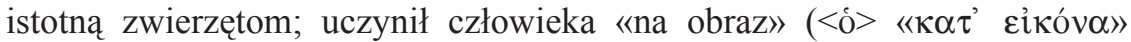

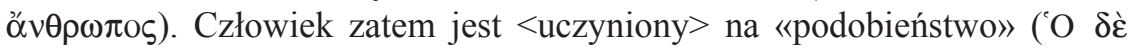

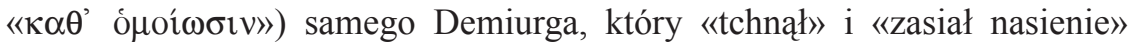

${ }^{34}$ Clemens Alexandrinus, Excerpta ex Theodoto I 2, 1, SCh 23, 54-56, thum. P. Siejkowski, ŹMT 22, 25-26.

${ }^{35}$ Tamże I 21, 1-3, SCh 23, 98-100, ŹMT 22, 40.

${ }^{36}$ Tamże II 37, SCh 23, 140, ŹMT 22, 51-52. 
w jego poprzedniku, w którym też za pośrednictwem Aniołów złożył coś współistotnego z sobą samym" ${ }^{37}$.

Zatem pierwszy człowiek, stworzony „na obraz”, posiadał „duszę hyliczną, bezrozumną, współistotną zwierzętom”. Drugi zaś został stworzony ,na «podobieństwo» samego Demiurga". Może się wydawać, że przytoczony powyżej opis dwóch różnych typów ludzi w zasadzie dotyczy jednego i tego samego człowieka - można przecież po prostu zaistnieć po tym, jak Demiurg (stwórca) tchnął życie - jednak później staje się jasne, że są to kompletnie różne osoby i że reprezentują dwa różne typy ludzkości. Zatem mit ten służy wyjaśnieniu pochodzenia walentynian - chrześcijan należących do „prawdziwego” Kościoła i reszty ludzkości oraz zagadnienia, gdzie leży przyczyna różnic między nimi. Nieco dalej Klemens przytacza wypowiedź Theodota:

„Począwszy od Adama, powstały trzy natury. Pierwsza, «bezrozumna» do której należał Kain; druga - «rozumna» i «sprawiedliwa» z której powstał Abel; trzecia - «pneumatyczna», a do niej należał Set. Zatem, człowiek ziemski jest «obrazem»; człowiek psychiczny - «podobieństwem» Boga; a pneumatyczny jest właściwą naturą Boga"38.

Z przytoczonego tekstu wyraźnie wynika, że trzy różne typy ludzi różnią się między sobą. Istota powstała ,na obraz”, jest zaledwie z prochu ziemi; ta, która powstała „na podobieństwo”, jest „,psychiczna”, a ta, która nie pozostaje w żadnej relacji do dwóch poprzednich, jest ,pneumatyczna”, ma swą własną naturę, wyraźnie różną od dwóch pozostałych. Koresponduje to z tym, co wiadomo o antropologii walentynian i sposobie, w jaki odnosili się oni do siebie samych oraz jak odróżniali sibie od reszty ludzkości. Według tej teorii ludźmi „,pneumatycznymi” czy „duchowymi”, niezwiązanymi z Demiurgiem, ponieważ nie mają tak niskiego statusu jak on, są walentynianie. Ludźmi ,,psychicznymi”, posiadającymi szansę dostapienia zbawienia (ale nie wszystkim się to uda) są zwykli chrześcijanie. Ludźmi ,z prochu”, nieposiadającymi w sobie nasienia i żadnego podobieństwa do duchowej dziedziny (Pleroma), a więc bez nadziei na jakiekolwiek odkupienie, sa pozostali ludzie. Idea ta znajduje swe bezpośrednie potwierdzenie w innej wypowiedzi Theodota:

„W tym też znaczeniu nasz Ojciec, Adam jest «pierwszym człowiekiem, uczynionym z ziemi, ziemskim» (por. 1Kor 15, 47). A ponieważ, jeśliby on zasiał nasienie z elementu psychicznego i pneumatycznego, tak jak uczynił to z elementu materialnego, to wszyscy bylibyśmy zrodzeni «równymi», «sprawiedliwymi» a «pouczenie» byłoby obecne we wszystkich. Oto dlaczego istnieje wielu hylików, niewielka liczba psychików, lecz nieliczni są pneumatycy. W ten sposób element pneumatyczny jest ocalony przez naturę, lecz element psychiczny posiada wolną wolę i zdolność do wiary i nieulegania

\footnotetext{
${ }^{37}$ Tamże III 50, 1-2, SCh 23, 162-164, ŹMT 22, 59-60.

${ }^{38}$ Tamże III 54, 1-2, SCh 23, 170, ŹMT 22, 61-62.
} 
zniszczeniu jak do niewiary i zniszczenia, zgodnie z własnym wyborem. Element materialny jest z natury skazany na zatracenie" 39 .

W zacytowanej wypowiedzi mamy do czynienia z pewnym rodzajem alegorycznej interpretacji opowiadania o stworzeniu Adama i o jego trzech synach. Dostrzegamy w niej także dopasowywanie opowieści biblijnej do gnostyckiego mitu, co było krytykowane przez pisarzy chrześcijańskich. Klemens kwestionuje też to, co postrzega jako determinizm kryjący się w pismach walentynian ${ }^{40}$.

Wypisy z Theodota zawierają również odniesienia do „lewej” i ,prawej” ręki, co koresponduje z tymi samymi kategoriami ludzi. Mówią one o tych ludzkich naturach, które będą zniszczone, i innych, które zostaną w końcu wzięte do Pleromy. Ci po prawej ,znają" Zbawcę ${ }^{41}$, podczas gdy ci po lewej byli stworzeni przez Demiurga pierwsi, zanim ten stworzył światło - co oznacza, że nie maja oni pokrewieństwa z tym światłem ${ }^{42}$.

„To, co jest po prawicy zostało wyłonione za dnia przez Matkę/Mądrość, jeszcze zanim prosiła o Światłość. Lecz nasienie Kościoła pojawiło się po tej prośbie, skoro elementy anielskie nasienia powstały z tego, co Męskie"43.

Najwyraźniej „nasienie Kościoła” to grupa posiadająca wyższość nad tymi „po lewej” i „po prawej” stronie. Grupy te wydają się korespondować z trzema - wyżej omówionymi - rodzajami ludzi: ci z ,lewej” z materialnymi, ci z ,prawej” z psychicznymi (o których Matka „,prosiła”) i „,nasienie Kościoła” z duchowymi (pneumatycznymi) gnostykami44. Ci ,po prawej” i ci ,po le-

${ }^{39}$ Tamże III 56, 1-3, SCh 23, 172-174, ŹMT 22, 62-63.

${ }^{40}$ Warto zauważyć, że Klemens w taki właśnie sposób odbiera doktrynę walentynian. Dlatego też jego przekaz nie jest jej dokładnym portretem, jaki dzisiaj znamy dzięki pogłębieniu badań nad myślą walentynian. W Wypisach z Theodota mamy do czynienia z heterodoksyjnym pisarzem, który mówi, że chrześcijanie (,psychicy”) są w stanie dostąpić zbawienia. Czy jednak zbawienie jest rozumiane jako pewien postęp od „obrazu” do „podobieństwa”, czy też przejście od wiary do gnozy? Tego jednoznacznie nie da się rozstrzygnaćc, jednak najwyraźniej istnieje jakaś forma duchowego postępu. W każdym razie, z tekstów z Nag Hammadi wyłania się mniej deterministyczny obraz gnostyków niż przedstawiany przez pisarzy chrześcijańskich w klasycznych pismach herezjologicznych. Por. L. Roig Lanzillotta, A Way of Salvation: Becoming Like God in Nag Hammadi, „Numen” 60 (2013) 71-102.

${ }^{41}$ Por. Clemens Alexandrinus, Excerpta ex Theodoto I 23, 3, SCh 23, 106, ŹMT 22, 42: „Zaraz po Męce Pana, był on posłany aby przepowiadać $<$ Ewangelię $>$. Dlatego też zwiastował on Zbawcę pod jednym albo drugim obrazem. $<$ W pierwszym wypadku $>$ jako zrodzonego i podległego $<$ Ojcu $>$ przez wzgląd na tych co będą po lewicy, gdyż mogli oni poznać jego w tym obrazie i lękać się Jego. $<$ W drugim wypadku>, według tego, co duchowe, jako pochodzącego z Ducha Świętego i Dziewicy, tak jak Go znają aniołowie po prawicy".

${ }^{42}$ Por. tamże II 34, 1, SCh 23, 134, ŹMT 22, 50: „A dalej, Moce po lewicy, wyłonione <z Matki>, przed tymi po prawicy, nie zostały ukształtowane przez nadejście Światłości, lecz owe Moce po lewicy zostały pozostawione Miejscu, aby Ono je ukształtowało".

${ }^{43}$ Tamże II 40, SCh 23, 144, ŹMT 22, 53.

${ }^{44}$ Jest to zgodne z wyjaśnieniem Ireneusza w Adversus haereses I 6, 1, SCh 264, 90, thum. 
wej" stronie wydają się też odnosić do dwóch różnych stron krzyża. Bierze się to z obserwacji poczynionej przez Theodota (lub innego cytowanego przez Klemensa walentyniańskiego pisarza), że eon zwany Staurosem (nazywany także Horos lub Metocheos), co znaczy „krzyż”, jest granicą pomiędzy Pleromą a światem stworzonym. Podobnie jak znak krzyża jest nie tylko granicą horyzontalną, ale również granicą wertykalną, która oddziela te rzeczy w stworzonym świecie:

„Krzyż jest znakiem Kresu w Pleromie, gdyż oddziela on niewiernych od wiernych, tak jak Kres rozdziela świat od Pleromy"45.

Przedstawione powyżej różne obrazy trzech typów ludzi służą wyraźniejszemu ukazaniu, w jaki sposób walentynianie radzili sobie z interpretacją tekstu $\mathrm{Rdz}$ 1, 26-27. Zagadnienie to z pewnością było bardzo istotne, gdyż Klemens Aleksandryjski, poprzez rozszerzoną interpretację opisu stworzenia człowieka (Rdz 1, 26-27), wiele uwagi poświęcił zwalczaniu interpretacji walentynian.

Interesujące jest, że Aleksandryjczyk przy własnej interpretacji biblijnego opisu stworzenia człowieka na obraz i podobieństwo Boga (Rdz 1, 26-27), nie dokonuje ani literalnej (czy dosłownej), ani alegorycznej interpretacji tekstu. Opowiadanie to odczytuje on w świetle innego mitu mówiącego o przejściu od

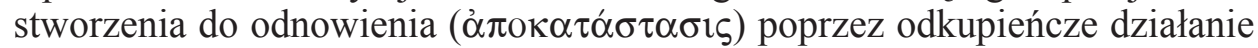
Chrystusa. Zatem interpretacja tego, mogłoby wydawać się mało znaczącego fragmentu Pisma Świętego, dopiero nabiera kształtu - zarówno dla Theodota, jak i dla Klemensa - na szerszym mitologicznym tle. Warto też zauważyć, że w czasach Klemensa chrześcijanie twierdzili, że fałszywi gnostycy nie byli w rzeczywistości chrześcijanami, lecz platonikami lub pitagorejczykami. Przykładowo, Hipolit stara się to wykazać poświęcając temu problemowi aż dziewięć rozdziałów VI księgi Refutatio omium haeresium ${ }^{46}$. Obecnie jest to przedmiotem dyskusji, ale pozostaje faktem, że mitologia walentyniańska obejmuje elementy biblijne, platońskie, pitagorejskie i hermetyczne, co też obecne jest w nauczaniu Klemensa, który próbuje dokonać syntezy myśli biblijnej i platońskiej, chociaż czyni to w zupełnie inny sposób.

\footnotetext{
W. Myszor, Ireneusz z Lyonu i gnostycy. Zdemaskowanie i odparcie fatszywej gnozy. Ttumaczenie: Adversus haereses Ksiega I i II, SACh SN 17, Katowice 2016, 44: „Istnieją zatem trzy elementy (w człowieku): materialny (hylikon), który nazywają też «lewym», ten, jak uczą, z konieczności ginie, ponieważ nie może przyjąć żadnego tchnienia niezniszczalności, psychiczny (psychikon), mówią o nim jako o «prawym», ponieważ znajduje się pośrodku, między duchowym (pneumatikon) i materialnym (hylikon), i idzie w tym kierunku, ku któremu się skłania. Element duchowy (pneumatikon) został wysłany po to, aby tu, w połączeniu z psychicznym i we wspólnym z nim wychowaniu, został ukształtowany".

${ }^{45}$ Clemens Alexandrinus, Excerpta ex Theodoto II 42, 1, SCh 23, 148, ŹMT 22, 53.

${ }^{46}$ Por. Hippolytus, Refutatio omnium haeresium VI 16-24.
} 


\title{
VALENTINUS' INTERPRETATION OF THE BIBLICAL DESCRIPTION OF THE CREATION OF MAN (GEN 1:26-27) IN CLEMENT OF ALEXANDRIA
}

\begin{abstract}
(Summary)
The article attempts to show the Valentinus' interpretation of the Biblical description of the creation of man (Gen 1:26-27) in Excerpta ex Theodoto prepared by Clement of Alexandria. The first part of the article shows the character of Valentinus and his school; the second part shows the importance of Excerpta for getting to know the Valentinian heresy; the third part analyzes the fragments of Excerpta ex Theodoto referring to the Biblical description of man's creation and to the anthropology proposed by Theodot - one of the representatives of the Eastern School.
\end{abstract}

Key words: Clement of Alexandria, Theodotus, Gnosticism, Valentinians, anthropology, exegesis Gen 1:26-27.

Słowa kluczowe: Klemens Aleksandryjski, Theodot, gnostycyzm, walentynianie, antropologia, egzegeza Rdz, 1, 26-27.

\section{BIBLIOGRAFIA}

\section{Źródła}

Clemens Alexandrinus, Excerpta ex Theodoto, éd. F. Sagnard, SCh 23, Paris 1948; The Excerpta ex Theodoto of Clement of Alexandria lub ed. with translation, introduction and notes by R.P. Casey, London 1934, tłum. P. Siejkowski, Klemens Aleksandryjski, Wypisy z Theodota, ŹMT 22, Kraków 2001.

Clemens Alexandrinus, Stromata, I, éd. C. Mondésert - M. Caster, SCh 30, Paris 1951, IV, éd. A. Van Den Hoek, SCh 463, Paris 2001, VI, éd. P. Descourtieux, SCh 446, Paris 1999, VII, éd. A. le Boulluec, SCh 428, Paris 1997, tłum. J. Niemirska-Pliszczyńska, Kobierce zapisków filozoficznych dotyczacych prawdziwej wiedzy, t. 1-2, Warszawa 1994.

Eusebius CAesariensis, Historia ecclesiastica, ed. i tłum. ŹMT 70 [wyd. grecko-polskie, oprac. H. Pietras, thum. A. Caba na podstawie tłum. A. Lisieckiego], Kraków 2013.

Hippolytus, Refutatio omnuium haeresium, ed. P. Wendland, GCS 26, Leipzig 1916, 1-293. Irenaeus, Adversus haereses, I, éd. A. Rousseau - L. Doutreleau, SCh 264, Paris 1979; III, éd. A. Rousseau - L. Doutreleau, SCh 211, Paris 1974, I-II, tłum. W. Myszor, Ireneusz z Lyonu i gnostycy. Zdemaskowanie i odparcie fatszywej gnozy. Ttumaczenie: Adversus haereses Księga I i II, SACh SN 17, Katowice 2016.

Tertullianus, Adversus Marcionem, ed. A. Kroymann, CCL 1, Turnhout 1954, 437-726, tłum. S. Ryznar: Tertulian, Przeciw Marcjonowi, PSP 58, Warszawa 1994.

Tertullianus, Adversus Praxean 3, ed. A. Kroymann - E. Evans, CCL 2, Turnhout 1954, 1157-1205, thum. E. Buszewicz: Tertulian, Przeciw Prakseaszowi, w: Trójca Święta, ŹMT 4, Kraków 1997, 35-86.

Tertullianus, Adversus Valentinianos, éd. J.-C. Fredouille, SCh 280, Paris 1980. 
Tertullianus, De praescriptione haereticorum, ed. R.F. Refoulé, CCL 1, Turnhout 1954, 185-224, tłum. E. Stanula: Tertulian, Preskrypcja przeciw heretykom, w: Tertulian, Wybór pism, PSP 5, Warszawa 1970, 40-78.

VÖLKER W., Quellen zur Geschichte der christlichen Gnosis, Tübingen 1932, 57-60.

Opracowania

Bienert W.A., Theodotos (der Gerber), LThK IX 1424.

Boulluec A. Le, Exégèse et polémique antignostique chez Irénée et Clément d'Alexandrie: l'example du centon, StPatr 17 (1982) 707-713.

Boulluec A. Le, Le notion d'hérésie dans la littérature grecque, II -III siècles, vol. 2: Clément d'Alexandrie et Origène, Études Augustiniennes, Paris 1985.

Clark E.A., Clement's use of Aristotle: The Aristotelian contribution to Clement of Alexandria's refutation of gnosticism, New York 1977.

Davison J.E., Structural Similarities and Dissimilarities in the Thought of Clement of Alexandria and the Valentinians, „Second Century” 3 (1983) 201-217.

Desjardins M., The Sources for Valentinian Gnosticism: A Question of Methodology, VigCh 40 (1986) 342-347.

DrączKowski F., Formy i cele modlitwy doskonatego chrześcijanina (gnostyka) wedtug Klemensa Aleksandryjskiego, w: Medytacja, Homo Meditans 1, red. W. Słomka, Lublin 1984, 127-132

DrączKowsKi F., Gnoza w ujęciu Klemensa Aleksandryjskiego, SACh 12 (1996) 9-21.

Draczkowski F., Miłość - Agape synteza chrześcijaństwa, Pelplin - Toruń 1997.

Edwards M., Catholicity and Heresy in the Early Church, Farnham 2009.

Edwards M., Clement of Alexandria and his Doctrine of the Logos, VigCh 54 (2000) 159-177.

Festugière A.-J., Notes sur les Extraits de Théodote de Clément d'Alexandrie, VigCh 3 (1949) 193-207.

Нітснсоск F.R.M., The Creed of Clement of Alexandria, „Hermathena” 12 (1902) no 28, $25-28$.

KAESTLI J.-D., Valentinisme italien et valentinisme oriental: leurs divergences à propos de la nature du corps de Jésus, w: The Rediscovery of Gnosticism: Proceedings of the International Conference on Gnosticism at Yale, New Haven, Connecticut, March 2831, 1978, ed. Bentley Layton, vol. 1, Leiden 1980, 391-403.

Kalvesmaki J., Eastern vs. Italian Valentinianism?, VigCh 61 (2008) 79-89.

Kovacs J.L., Clement of Alexandria and the Vallentinian Gnostics, New York 1978.

Kovacs J.L., Clement of Alexandria and Valentinian Exegesis in the „Excerpts from Theodotus", StPatr 41 (2006) 187-200.

Kovacs J.L., Echoes of Valentinian Exegesis in Clement of Alexandria and Origen, w: Origeniana Octava, ed. L. Perrone, Leuven 2004, 317-329.

Kovacs J.L., Grace and Works: Clement of Alexandria's Response to Valentinian Exegesis of Paul, w: Ancient Perspectives on Paul, ed. T. Nicklas - A. Merkt - J. Verheyden, Göttingen 2013, 191-210.

Lach-BARTLIK L., Wykaz drukowanych prac Ks. prof. dr. hab. Wincentego Myszora, VoxP 32 (2012) t. 57, 21-34.

Lilla S.R.C., Clement of Alexandria: A Study in Christian Platonism and Gnosticism, London 1971.

Longosz S., Ks. prof. Wincenty Myszor (22 V 1941 - 19 II 2017). Polski odkrywca gnozy wczesnochrześcijańskiej, VoxP 37 (2017) t. 68, 825-838.

Myszor W., Theodotos, Gnostiker, LThK IX 1425-1426. 
Osborn E.F., Reason and the Rule of Faith in the Second Century AD, w: The Making of Orthodoxy: Essays in Honour of Henry Chadwick, ed. R. Williams, Cambridge 1989, 40-61.

Procter E., Christian Controversy in Alexandria: Clement's Polemic against the Basilideans and Valentinians, New York 1995.

Quispel G., Gnoza, tłum. B. Kita, Warszawa 1988.

Roig Lanzillotta L., A Way of Salvation: Becoming Like God in Nag Hammadi, „Numen” 60 (2013) 71-102.

SAGnard F., Introduction, w: Clément d'Alexandrie: Extraits de Théodote, SCh 23, Paris 1948, 5-50.

SiEJKowski P., Wstęp, w: Klemens Aleksandryjski, Wypisy z Theodota, ŹMT 22, Kraków 2001, 5-19.

Simonetti M., Teodoto di Bisanzio (Banchiere), NDPAC III 5271.

Simonetti M., Teodoto di Bisanzio (Cuoiaio), NDPAC III 5271.

SimonetTi M., Teodoto valentiniano, NDPAC III 5272.

The Rediscovery of Gnosticism: Proceedings of the International Conference on Gnosticism at Yale, New Haven, Connecticut, March 28-31, 1978, ed. Bentley Layton, vol. 1-2, Leiden 1980.

Thomassen E., The Spiritual Seed: The Church of the „, Valentinians”, Leiden 2008.

ZMorzanKa A., Walentyn, EK XX 163-164.

ZMORZANKA A., Walentyn, PEF IX 688-690. 
